\title{
Sistem Informasi Manajemen Keuangan Pada LPBB Bintang Solusi Mandiri
}

\author{
${ }^{1}$ Sri Rahayu, ${ }^{2}$ Bambang Prasetya A, ${ }^{3}$ Praseto Wibowo Y \\ 1,2,3 Pendidikan Teknik Informatika dan Komputer Fakultas Tekni \\ Universitas Negeri Jakarta \\ ${ }^{1}$ srirahayuu05@gmail.com, ${ }^{2}$ bambangpadhi@unj.ac.id, ${ }^{3}$ prasetyo.wy@unj.ac.id
}

\begin{abstract}
Abstrak
Sistem informasi manajemen keuangan adalah sistem informasi yang digunakan untuk melihat transaksi, laporan dan melakukan proses pencatatan transaksi baik pendapatan maupun pengeluaran yang dilakukan oleh user yang berbeda yaitu manajer keuangan, manajer cabang dan admin. Pembuatan laporan dapat dilakukan secara otomatis oleh sistem tanpa harus memindahkan daftar transaksi ke jurnal secara manual sehingga pembuatan laporan lebih efisien dalam penggunaan waktu dan tenaga. Sebab apabila jumlah pendapatan dan pengeluaran yang terjadi cukup banyak, akan membutuhkan waktu dan tenaga kerja yang banyak untuk melaksanakan pengelolaan pembuatan laporan tersebut. Untuk itu pihak pengelola harus dapat mengatasi masalah tersebut agar proses pengelolaan dapat berjalan dengan cepat dan lancar. Karya akhir ini disusun dengan tujuan peneliti ingin mengembangkan sistem informasi manajemen keuangan pada LPBB Bintang Solusi Mandiri. Proses pengembangan sistem informasi ini menggunakan database, dimana sistem informasi ini menggunakan metode rational unified process (RUP). Setelah sistem informasi berhasil dibangun sistem informasi manajemen keuangan tersebut siap digunakan dan pembutan laporan keuangan yang sebelumnya memerlukan waktu satu bulan dan tenaga serta konsentrasi, sedangkan dengan sistem informasi untuk membuat laporan keuangan hanya membutuhkan waktu kurang dari lima menit. Sistem informasi manajemen keuangan dapat diakses pada host client yang telah terinstall sistem informasi manajemen keuangan dan telah terkoneksi dengan server.
\end{abstract}

Kata kunci : sistem informasi, manajemen keuangan, Rational Unified Process (RUP), User Acceptence Test (UAT)

\section{PENDAHULUAN}

Lembaga Pendidikan dan Bimbingan Belajar Bintang Solusi Mandiri (LPBB Bintang Solusi Mandiri) adalah lembaga yang bergerak di bidang pendidikan, lembaga tersebut dibentuk pada tahun 2008. Setiap lembaga membutuhkan sistem keuangan, sistem keuangan merupakan hal yang sangat penting demi berlangsung dan berkembangnya lembaga tersebut, kelancaran kinerja suatu lembaga khususnya lembaga bidang pendidikan sangat dipengaruhi oleh kelancaran kinerja bidang keuangan. Namun berdasarkan data yang diperoleh dari hasil analisis perkembangan keuangan LPBB Bintang Solusi Mandiri yaitu sejak tahun 2012 mengalami penurunan. Aktifitas pencatatan cashflow pada LPBB Bintang Solusi Mandiri dilakukan oleh bidang keuangan atau admin. Hingga saat ini pencatatan cashflow pada
LPBB Bintang Solusi Mandiri masih menggunakan sistem manual, belum ada aplikasi yang mendukung dalam pencatatan cashflow tersebut, sehingga semakin banyak permasalahan yang muncul, seperti terjadinya manipulasi data dan proses pengumpulan data dalam pembuatan laporan keuangan memerlukan waktu yang lama, hal tersebut dapat menimbulkan adanya penyimpangan dana dan membawa pengaruh negatif terhadap bidang lain. Oleh karena itu dibutuhkan sebuah sistem informasi manajemen keuangan yang dapat menyimpan dan mengolah data transaksi juga membuat laporan keuangan secara otomatis. 
II. KERANGKA TEORI

\subsection{Sistem Informasi Manajemen Keuangan}

Sistem informasi manajemen keuangan digunakan untuk membantu proses pengolahan data keuangan yang disajikan dalam laporan keuangan berdasarkan sistem pencatatan akuntansi. Akuntansi menyediakan laporan keuangan yang dibutuhkan oleh manajer keuangan dalam bentuk neraca, laporan laba rugi serta laporan perubahan modal, oleh karena itu sistem informasi manajemen keuangan kerap disebut dengan sistem informasi akuntansi (SIA).

Kebutuhan akan sistem informasi keuangan berawal dari subsistem input yang meliputi sistem informasi akuntansi, subsistem pemeriksaan internal dan subsistem penyelidikan keuangan. ketiga unsur tersebut berperan sebagai database yang berasal dari sumber internal organisasi dan lingkungan. Kemudian database diolah dan menjadi subsistem output untuk memperkirakan berapa besar anggaran yang dialokasikan dan berapa biaya yang harus dikeluarkan tersebut. Tahapan subsistem input, database dan subsistem output merupakan bahan pertimbangan bagi para pengambil kebijakan keuangan perusahan. Model yang dikemukakan tersebut diharapkan menjadi sistem pendukung keputusan bidang keuangan, sehingga dalam anggaran perusahaan alokasi biaya akan tepat sasaran dan proses pengendalian akan lebih mudah dilakukan (Rochaety, Setyowati, dan Ridwan,2011:98).

\subsection{Laporan Keuangan Pada Manajemen}

\section{Keuangan}

Untuk dapat menganalisa dan mengelola arus kas yang terjadi dalam suatu perusahaan, manajer keuangan membutuhkan laporan keuangan yang merepresentasikan keadaan keuangan pada organisasi tersebut. Menurut Haryono Jusuf (2011:27-31) laporan keuangan utama yang dihasilkan dari proses akuntansi terdiri atas :

1. Neraca

2. Laporan Laba-Rugi

3. Laporan Perubahan Modal

4. Laporan Arus Kas atau Jurnal

Pada umumnya laporan keuangan disusun setahun sekali, namun ada pula perusahaan yang menyusun laporan keuannya tiap kuartal, atau bahkan tiap bulan.

\subsubsection{Neraca}

Neraca atau sering disebut juga laporan posisi keuangan adalah suatu daftar yang menggambarkan aset (harta kekayaan), kewajiban, dan modal (ekuitas) yag dimiliki oleh suatu entitas (perusahaan) pada suatu saat tertentu. Judul suatu neraca terdiri atas nama entitas atau perusahaan, nama laporan, dan tanggal neraca. Badan isi laporan terdiri atas tiga bagian yaitu aset, kewajiban, dan modal, seperti terlihat pada gambar 2.1 .

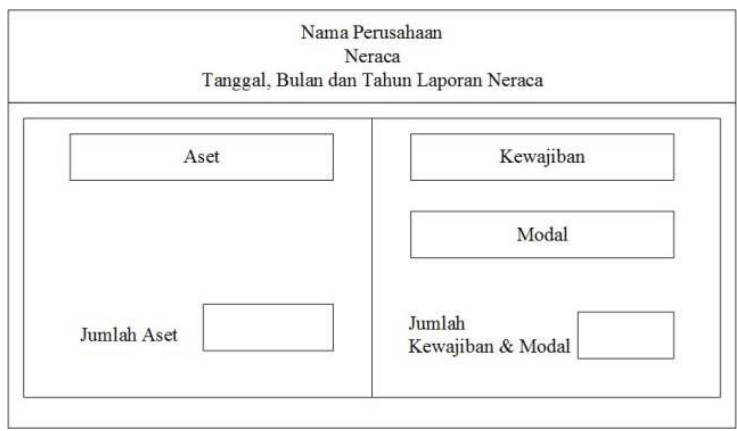

\section{Gambar 2. 1 Contoh Bentuk Laporan Neraca}

\subsubsection{Aset}

Aset adalah sumber-sumber ekonomi yang dimiliki perusahaan biasa dinyatakan dalam satuan uang. Kewajiban adalah utang yang harus dibayar 
oleh perusahaan dengan uang atau jasa pada suatu saat tertentu dimasa yang akan datang. Modal atau ekuitas adalah hak pemilik perusahaan atas kekayaan (Aset) perusahaan. Jumlah aset selalu sama dengan jumlah kewajiban ditambah modal. Hubungan ini dapat dinyatakan dalam bentuk persamaan sebagai berikut :

$$
\text { Aset }=\text { Kewajiban }+ \text { Modal }
$$

\subsubsection{Laporan Laba-rugi}

Laporan laba-rugi disusun dengan maksud untuk menggambarkan hasil operasi perusahaan dalam suatu periode waktu tertentu, dengan kata lain laporan laba-rugi menggambarkan keberhasilan atau kegagalan operasi perusahaan dalam upaya mencapai tujuannya. Hasil operasi perusahaan diukur dengan membandingkan antara penghasilan perusahaan dengan beban yang dikeluarkan untuk memperoleh penghasilan tersebut. Apabila penghasilan lebih besar daripada beban, perusahaan dinyatakan memperoleh laba, apabila penghasilan lebih kecil daripada beban berarti perusahaan dinyatakan menderita rugi. Contoh bentuk laporan laba-rugi terlihat pada gambar 2.2.

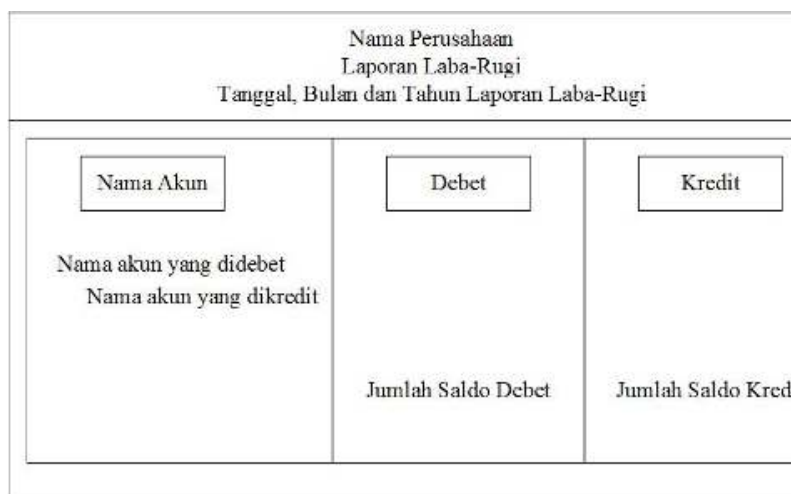

Gambar 2. 2 Contoh Bentuk Laporan Laba-

Rugi

Judul pada laporan laba-rugi terdiri atas nama perusahaan, nama laporan, dan periode laporan, isi laporan laba-rugi terdiri atas tiga komponen yaitu penghasilan, beban dan laba rugi.

Penghasilan adalah penerimaan kas atau aset lain yang diterima dari konsumen sebagai hasil penjualan barang atau pemberian jasa, penghasilan meliputi pendapatan dan keuntungan, beban adalah beban perolehan aset yang dikonsumsi atau jasa yang digunakan dalam proses memperoleh pendapatan. Laba adalah selisih lebih atau kurang antara pendapatan dan beban.

\subsubsection{Laporan Perubahan Modal}

Laporan perubahan modal adalah hasil operasi perusahaan yang berupa laba atau rugi akan berpengaruh terhadap modal pemilik, apabila perusahaan memperoleh laba, maka laba tersebut akan menambah modal pemilik, sebaliknya apabila memperoleh rugi maka modal pemilik akan berkurang. Modal pemilik akan bertambah ketika adanya penambahan investasi oleh pemilik, adanya laba yang didapat. Sedangkan modal akan berkurang ketika pemilik melakukan pengambilan aset perusahaan untuk keperluan pribadi dan ketika perusahaan menderita rugi. Gambar 2.3 adalah contoh bentuk laporan perubahan modal.

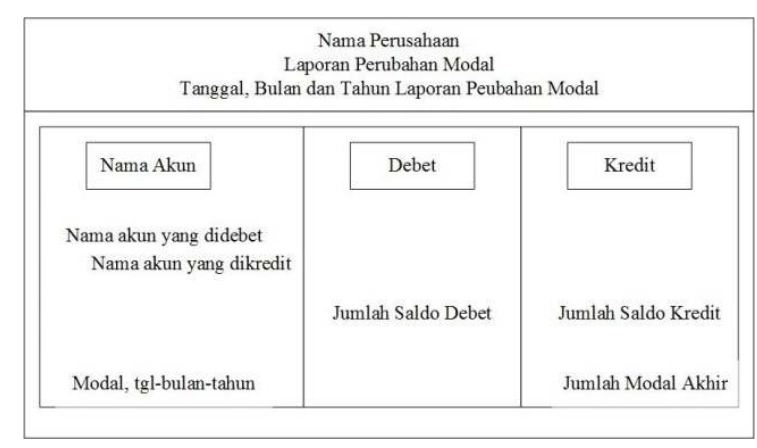

Gambar 2. 3 Contoh Bentuk Laporan

Perubahan Modal

Laporan perubahan modal sering disebut juga sebagai jembatan antara laporan laba-rugi dengan neraca, data laba atau rugi yang tercantum 
dala laporan laba-rugi pada akhirnya mempengaruhi modal pada neraca.

\subsubsection{Jurnal}

Jurnal adalah alat yang digunakan untuk mencatat transaksi perusahaan yang dilakukan secara kronologis (berdasarkan urutan waktu terjadinya dengan menunjukan akun yang harus didebet dan dikredit beserta jumlah rupiahnya. Contoh bentuk junal terlihat pada gambar 2.4.

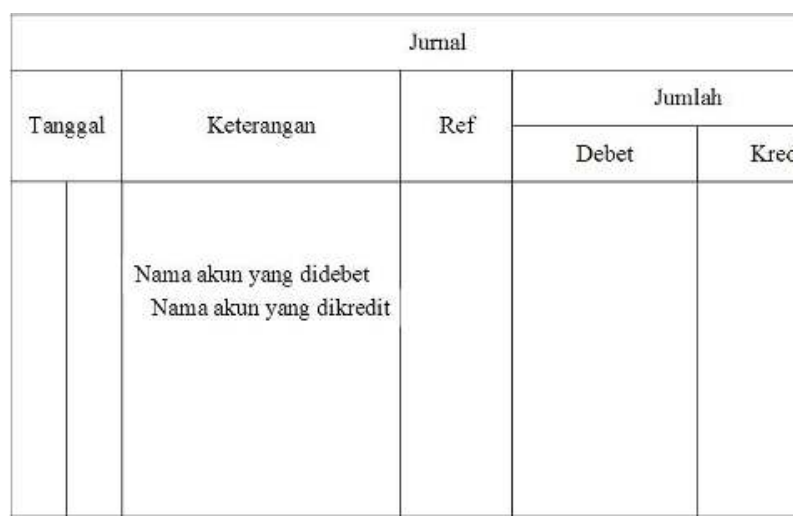

\section{Gambar 2. 4 Contoh Bentuk Jurnal}

\subsection{Model Rational Unified Process (RUP)}

\section{Rational Unified Process (RUP)}

merupakan sebuah proses pengembangan sistem yang menyediakan serangkaian prosedur dalam menetapkan tugas dan tanggung jawab dalam tim pengembangan (Grady Booch, James Rumbaugh, and Ivar Jacobson:1999). RUP juga merupakan suatu kerangka kerja proses yang dapat disesuaikan dan dikembangkan di setiap organisasi untuk memenuhi kebutuhan organisasi tersebut. RUP mendukung teknik pengembangan sistem yang berorientasi objek.

\section{METODOLOGI PENELITIAN}

\subsection{Metode Penelitian}

Penelitian yang digunakan oleh penulis adalah penelitian Research and Development (R\&D). Metode penelitian R\&D adalah metode penelitian yang digunakan untuk menghasilkan produk tertentu, dan menguji keefektifan produk tersebut (Sugiono,2009:407).

Untuk memenuhi data yang dibutuhkan dalam pengembangan produk, maka penulis melakukan kegiatan observasi, wawancara, dan studi literatur. Yang kemudian data yang dikumpulkan dapat disesuaikan dengan keadaan sebenarnya dan dan dibandingkan dengan teori yang menunjang.

\subsection{Metode Pendekatan dan Pengembangan Sistem}

\subsubsection{Metode Pendakatan Sistem}

Metode pendekatan sistem yang digunakan adalah dengan menggunakan pendekatan Object Oriented yang digambarkan dengan UML dan diantaranya adalah Use Case Diagram, Activity Diagram, Sequence Diagram, Class Diagram.

\subsubsection{Metode Pengembangan Sistem}

Metode pengembangan perangkat lunak yang digunakan untuk merancang dan membangun aplikasi manajemen keuangan pada LPBB Bintang Solusi Mandiri adalah metode RUP ( Rational Unified Process ). Seperti telah dijelaskan pada bab sebelumnya, RUP merupakan salah satu metode dari pengembangan perangkat lunak berbasis objek. Dengan aktifitas yang berfokus pada pengembangan model dengan menggunakan Unified Model Language (UML). 


\section{3}

Implementasi dan Pengujian Sistem

Pengujian sistem informasi dilakukan setelah sistem informasi yang dibangun dapat diimplementasikan. Pengujian yang dilakukan dalam penelitian ini dengan menggunakan User Acceptence Test. Perancangan perangkat lunak akan diuji di setiap unit program, sehingga dapat disimpulkan apakah sistem informasi yang dibangun telah sesuai dengan keinginan user pada tahap requirements definition.

\subsubsection{Pengujian Fungsional}

Teknik pengujian dilakukan dengan cara melakukan pengujian software. Teknik pengujian software dengan melakukan uji fungsional adalah proses untuk memastikan tidak adanya kesalahan fungsional pada sistem informasi manajemen keuangan pada LPBB Bintang Solusi Mandiri. Skenario proses sistem dilakukan oleh semua user, MK adalah user dengan jabatan manajer keuangan, MC adalah user dengan jabatan manajer cabang, sedangkan $\mathrm{AD}$ adalah user dengan jabatan admin.

\subsubsection{User Acceptence Test}

User acceptence test yaitu proses pengujian oleh user dan menghasilkan dokumen untuk dijadikan bukti bahwa aplikasi yang dikembangkan dapat diterima oleh user dan hasil pengujiannya dianggap memenuhi kebutuhan.

Pengujian dilakukan dengan skenario proses yang telah ditentukan. Pengujian user acceptence test dilakukan kepada tiga orang yaitu manajer keuangan, manajer cabang, dan admin. Ketiga orang tersebut yeng telah memberikan requirement untuk membangun sistem informasi manajemen keuangan

\section{HASIL DAN PEMBAHASAN}

4.1 Hasil Penelitian

Observasi atau pengamatan secara langsung pada LPBB Bintang Solusi Mandiri dilakukan untuk mengetahui bagaimana sistem yang berjalan di lembaga tersebut khususnya alur transaksi mulai dari penerimaan atau pengeluaran sampai dengan pencatatan dan penyajian laporan, hasil observasi lain yaitu daftar jadwal kelas bimbingan belajar.

Hasil dari observasi adalah sebagai berikut :

1. Sistem Pendapatan

Pendapatan LPBB Bintang Solusi Mandiri bersumber dari pemodal dan pendapatan siswa. Banyaknya jumlah modal yang ditanamkan oleh pemodal, dan banyaknya jumlah pendapatan yang bersumber dari siswa berbeda-beda. Jumlah pendapatan siswa tergantung pada jenjang pendidikan siswa tersebut.

2. Sistem pengeluaran

Pengeluaran di LPBB Bintang Solusi Mandiri dilakukan untuk memenuhi kebutuhan perusahaan atau membayar kewajiban serta beban dari usaha.

3. Sistem pencatatan

Setelah terjadinyan pendapatan dan pengeluaran, Admin atau manajer cabang memasukan data transaksi tersebut ke dalam buku besar dan Ms. Excel dan menyimpannya.

\section{Sistem pembuatan laporan}

Pembuatan laporan keuangan dilakukan diakhir bulan, laporan tersebut dibuat secara manual dan memastikan data pada kwitansi dengan Ms. Excel dan buku besar sesuai. Laporan keuangan adalah seluruh data yang disimpan pada Ms. Excel dan 
pada buku besar pada satu bulan. LPBB Bintang Solusi Mandiri tidak menggunakan laporan keuangan seperti jurnal, neraca, laba rugi dan perubahan modal.

\subsection{Hasil Analisis dan Desain}

Setelah melakukan penelitian dan mendapatkan gambar tentang sistem informasi manajemen LBB BSM , peneliti melakukan analisis dan desain terhadap sistem informasi yang akan dibuat

\section{Use Case Diagram}

Sebuah use case merepresentasikan sebuah interaksi antara aktor dengan sistem. Use case merupakan sebuah pekerjaan tertentu. Misalnya pada sistem informasi manajemen keuangan terdapat use case dengan aktor manajer keuangan, manajer cabang, dan admin.

\section{Sequence Diagram}

Sequence diagram biasanya digunakan untuk menggambarkan skenario atau rangkaian langkah-langkah yang dilakukan sebagai respons dari sebuah event untuk menghasilkan output tertentu.

\section{Class Diagram}

Class yang terdapat pada class diagram sistem informasi manajemen keuangan adalah mastercustumer, masterharga, jadwal, masterkategoriharga, daftar, piutang, modal, perubahanmodal, modalsebelumpenyesuaian, pendapatan, pengeluaran, transaksi, kewajiban, utangusaha, aset, masterakun, beban, masterpengeluaran, dan masterpendapatan.

\subsection{Hasil Pengujian Sistem}

\subsubsection{Hasil Pengujian Fungsional}

Hasil pengujian fungsional adalah hasil pengujian yang dilakukan sesuai dengan prosedur penelitian pengujian fungsional. Hasil dari pengujian fungsional yang didapat adalah seluruh fungsional program berfungsi dengan benar.

\subsubsection{Hasil Pengujian User Acceptence Test}

Hasil pengujian kebutuhan adalah hasil pengujian yang dilakukan sesuai dengan prosedur penelitian user accepetence test. Sistem informasi yang dihasilkan sesuai dengan requirement dari user. Sehingga dapat di terima oleh user.

\subsection{Pembahasan}

\subsubsection{Pembahasan Kebutuhan}

Pada pembahasan kebutuhan akan dibahas hasil dari skenario pengujian yang terdapat pada user acceptance test. Hasil dari user acceptence test yang dilakukan adalah sistem informasi yang dibangun sesuai dengan requirement yang diajukan oleh perusahaan. Untuk mengakses sistem informasi manajemen keuangan dibutuhkan jaringan internet untuk mendukung koneksi dari client ke server. Gambaran arsitektur jaringan terlihat seperti gambar 4.1.

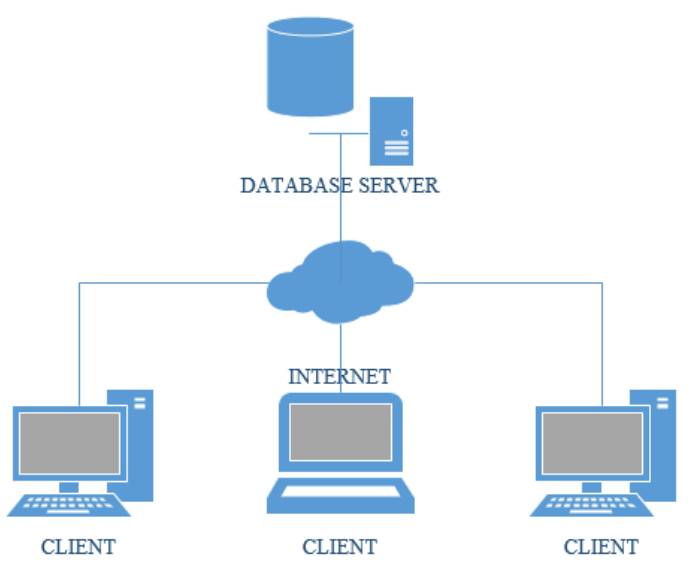

Gambar 4. 1 Arsitektur Jaringan

\subsection{Fasilitas pada Sistem}

Berikut adalah fasilitas atau fitur yang terdapat pada sistem. 
1. Aplikasi dapat menyimpan master data siswa, master akun, master pendapatan, master pengeluaran, master harga, master jadwal, transaksi, aset, beban, kewajiban, dan modal.

2. Aplikasi dapat menghitung jumlah piutang siswa yang belum dibayar, jumlah aset, jumlah kewajiban, jumlah modal, jumlah beban, jumlah debet dan kredit, jumlah laba rugi berdasarkan rentang waktu tertentu.

3. Aplikasi dapat menampilkan laporan neraca setiap bulan

4. Aplikasi dapat menampilkan laporan laba rugi setiap bulan

5. Aplikasi dapat menampilkan laporan perubahan modal setiap bulan

6. Aplikasi dapat menampilkan laporan arus kas/jurnal setiap bulan.

7. Aplikasi dapat mencetak bukti transaksi pemasukan

8. Aplikasi dapat mencetak bukti transaksi pengeluaran

9. Aplikasi dapat mencetak laporan neraca

10. Aplikasi dapat mencetak laporan laba rugi

11. Aplikasi dapat mencetak laporan perubahan modal

12. Aplikasi dapat mencetak laporan arus kas atau jurnal

13. Aplikasi hanya dapat diakses oleh user yang memiliki wewenang terhadap aplikasi, yaitu manajer keuangan, manajer cabang, dan admin

14. Aplikasi berbasis jaringan client server, pada host client terdapat aplikasi client, dan pada server terdapat database

\section{KESIMPULAN}

5.1 Kesimpulan

Berdasarkan pada sistem pencatatan

keuangan di LPBB Bintang Solusi Mandiri dengan menggunakan sistem informasi manajemen keungan yang dikembangkan adalah sebagai berikut :

1. Sistem informasi manajemen keuangan yang telah dibangun dapat mempermudah pengerjaan proses pencatatan transaksi yang dilakukan pada LPBB Bintang Solusi Mandiri, dikarenakan user dapat memasukan transaksi pengeluaran atau pendapatan hanya dengan memasukan data transaksi dan menekan tombol simpan maka secara otomatis data transaksi tersimpan ke dalam database dan bukti transaksi disajikan dalam bentuk PDF.

2. Sistem informasi manajemen keuangan yang telah dibangun mempercepat pengerjaan proses pembuatan laporan keuangan yang dibutuhkan oleh LPBB Bintang Solusi Mandiri setiap bulannya. Dikarenakan user hanya dapat melihat laporan keuangan dengan memasukan periode laporan dan secara otomatis laporan keuangan ditampilkan. Dengan kemudahan dan kecepatan proses pembuatan laporan tersebut, user dapat memiliki waktu yang lebih banyak untuk melakukan kegiatan lain yang dapat meningkatkan perkembangan perusahaan.

3. Sistem informasi manajemen keuangan memiliki layanan seperti mendaftar sebagai user, mengubah password, melakukan pencarian transaksi yang telah terjadi, menyimpan dalam bentuk PDF bukti transaksi dan laporan keungan, melihat laporan neraca, laba rugi, perubahan modal, dan jurnal. Serta jabatan penerima pendapatan dan user yang mengeluarkan pengeluaran secara otomatis dicantumkan dibukti pendapatan dan pengeluaran. 
Dalam pembangunan sistem informasi manajemen keuangan pada LPBB Bintang Solusi Mandiri masih terdapat banyak kekurangan yang perlu diperbaiki dan dilakukan penyempurnaan kembali, yaitu :

1. Untuk mengakses sistem informasi manajemen keuangan bisa dilakukan di gedung yang berbeda dengan menggunakan jaringan VPN. Sehinga manajer cabang dapat melihat kondisi keuangan pada cabang secara jarak jauh.

2. Menambahkan fungsi menghubungkan ke printer dan mencetak secara otomatis bukti transaksi secara otomatis. Sehingga user tidak perlu menyimpan bukti transaksi dalam bentuk PDF.

\section{DAFTAR PUSTAKA}

Eti Rochaety, Tupi Setyowati, dan Faisal Ridwan Z. (2011). Sistem Informasi Manajemen. Jakarta: Wacana Media

Grady, Robert B. (1992).Practical Software Matrics For Project Management and Process Improvement. Englewood Cliffs NJ : Prentice Hall

Jusup, AI Haryono. (2011). Dasar-dasar Akuntansi Jilid 1 Edisi 7. Yogyakarta:STIE YKPN

Sugiono. (2010). Metode Penelitian Kuantitatf, Kualitatif dan R\&D. Bandung: Alfabetha 